\title{
The Urban Population in Finland 1815-1865
}

\author{
OIVA TURPEINEN
}

\author{
Assistant \\ Department of History \\ University of Helsinki
}

\section{Introduction}

I have previously discussed the development of the Finnish urban population in 1727-1810 (Turpeinen 1977). It was natural for this study, which was based on register material and church population records, to extend to the beginning of the 1800s. It was at this time that towns were separated into a group of their own in the statistical system used in Finland: beginning in 1802 in the population change tables and in 1805 in the population tables.

Thus it could be assumed a relatively easy task to obtain population figures for the towns starting in 1805 from the population tables kept in the archives of the Finnish Central Statistical Office. In reality, however, this is a rather complicated matter. The problems that arise already appeared in a book published in 1899 titled $»$ The main features of the Finnish population statistics in 1750-1890 I. The state of the population" ("Pääpiirteet Suomen väestötilastosta vuosina 1750-1890 I. Väestön tila». Suomenmaan virallinen tilasto VI, Väkiluvun tilastoa 29, Helsinki 1899). Thus, for example, the following figures concerning the population of Viipuri are presented in the book mentioned (p. 4): 8,618 in $1850,5,421$ in 1860 and 8,742 in 1865 . Later these figures keep popping up in town histories (see e.g. Hautala 1975, p. 119). Just from a glance at these figures, however, the question arises how it can be possible for swings such as these to have occurred in the population without the town having experienced a violent crisis between 1850 and 1860 or an annexation of land in $1860-65$.

How can population variations like these be explained? A closer examination in this case shows that the variation in Viipuri was mainly due to Russian troops stationed in the town. Similar problems were caused for this same reason in other towns also. Partially for this reason Orthodox urban parishes, in which Russian troops were at times included, have systematically been excluded from this study. Another reason for their exclusion is that the population change tables of the Orthodox parishes are incomplete. However, Finnish military units, special institutions etc. have been included, because information on changes in their population has usually remained intact. 


\section{Sources, method and previous research}

This study will attempt to answer the following questions: (1) How did the population in different Finnish towns develop in 1815-1865, (2) How did fertility, mortality and migration affect the development of the population, (3) What was the urban population structure like and (4) What factors economic, political etc. - were in the background affecting population factors and thus the development of the urban population?

The main sources used in the study are population and population change tables. The former were kept every five years and the latter annually. With this data we can compare not only population development in different towns but also differences in fertility and mortality. The focal point of this study is thus on the comparison of population and factors which affect it.

Although no basic study of the development of the Finnish urban population and the reasons for its development has been made for the years $1815-65$, some studies have touched on the subject (Jutikkala 1977 and Nikula 1981). Similarly, some province histories have included an examination of the development of the area's urban population (Wirilander 1960 and Rosenberg 1976). The most thorough examination of the subject can be found in town histories, although it must be said here that there are quite large qualitative differences in the way this question has been handled (see the bibliography and source list at the end of this article).

\section{Population development}

In 1815 there were a total of 29 towns in Finland and in 1865 there were 33, for during this period the following towns were founded: Jyväskylä (1837), Mikkeli (1838), Joensuu (1848) and Mariehamn (1861).

In examining the size of these towns and changes which had occurred, we arrive at the following:

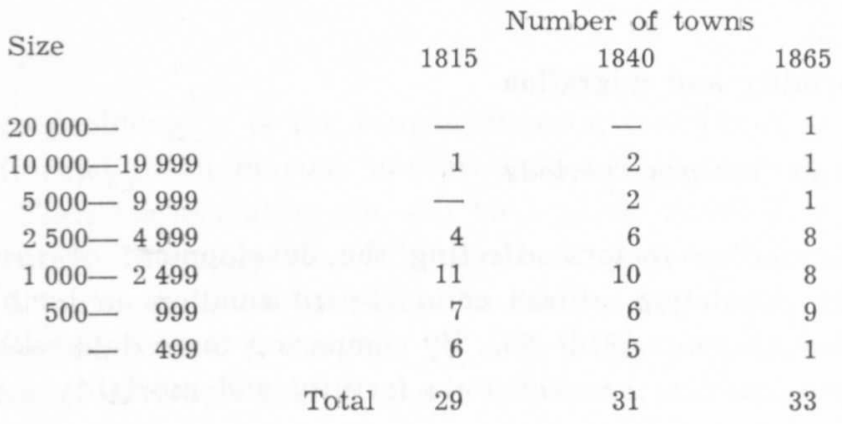


A general developmental feature was the growth of the towns. While there were only five towns in 1815 with more than 2,500 inhabitants, in 1840 there were already 10 and in 1865 15. This phenomenon was a result of the fact that the entire urban population of Finland grew in half a century from 51,100 to 120,900 , by almost 2.4 times. The new towns which were founded during the period covered by the study had little effect on this development, for even without them the figure for 1865 would be 118,000 .

The towns of Finland - appendix table 1 - can also be divided into three main groups, namely towns situated on the Gulf of Finland, those on the Gulf of Bothnia and those in the interior (see below).

$\begin{array}{lrrrrrr} & \begin{array}{r}1815 \\ \text { population }\end{array} & \% & \begin{array}{r}1840 \\ \text { population }\end{array} & \% & \text { population } & \% \\ & & & & & & \\ \text { Gulf of Finland } & 13,418 & 26.2 & 30,051 & 36.6 & 43,102 & 35.6 \\ \text { Gulf of Bothnia } & 32,195 & 63.0 & 41,496 & 50.5 & 56,218 & 46.5 \\ \text { Interior } & 5,519 & 10.8 & 10,625 & 12.9 & 21,608 & 17.9\end{array}$

The towns on the Gulf of Finland, whose number remained at six throughout the period under study, included Helsinki, Loviisa, Porvoo, Tammisaari, Hamina and Viipuri. The largest number of towns was on the Gulf of Bothnia. In this area their number rose by one to 15 , because Mariehamn has been included in this group. Among the new towns founded in 1815-65 three were in the interior, so this group rose from 9 towns to 12 .

The following conclusion can be made from the numbers cited above: the proportion of towns on the Gulf of Bothnia dropped sharply during this fiftyyear period. Correspondingly the percentage of towns on the Gulf of Finland and in the interior rose markedly.

In regard to population size Helsinki and Turku were in a class of their own. For this reason these towns were made into a subgroup of their own in the adjacent figure (Figure 1). Figure 1, which was drawn on the basis of appendix table 1 , shows how the population of Helsinki grew rapidly until the beginning of the $1840 \mathrm{~s}$ and how in the same period the population of Turku stood almost at a standstill.

\section{Fertility, mortality and migration}

\section{Development in five-year periods}

Among population factors affecting the development of the size of the Finnish urban population, almost complete information on births and deaths is available for the years 1816-65. By comparing these data with the average population size, we can then calculate fertility and mortality. 
Figure 1. The population of Finnish towns 1815-1865.

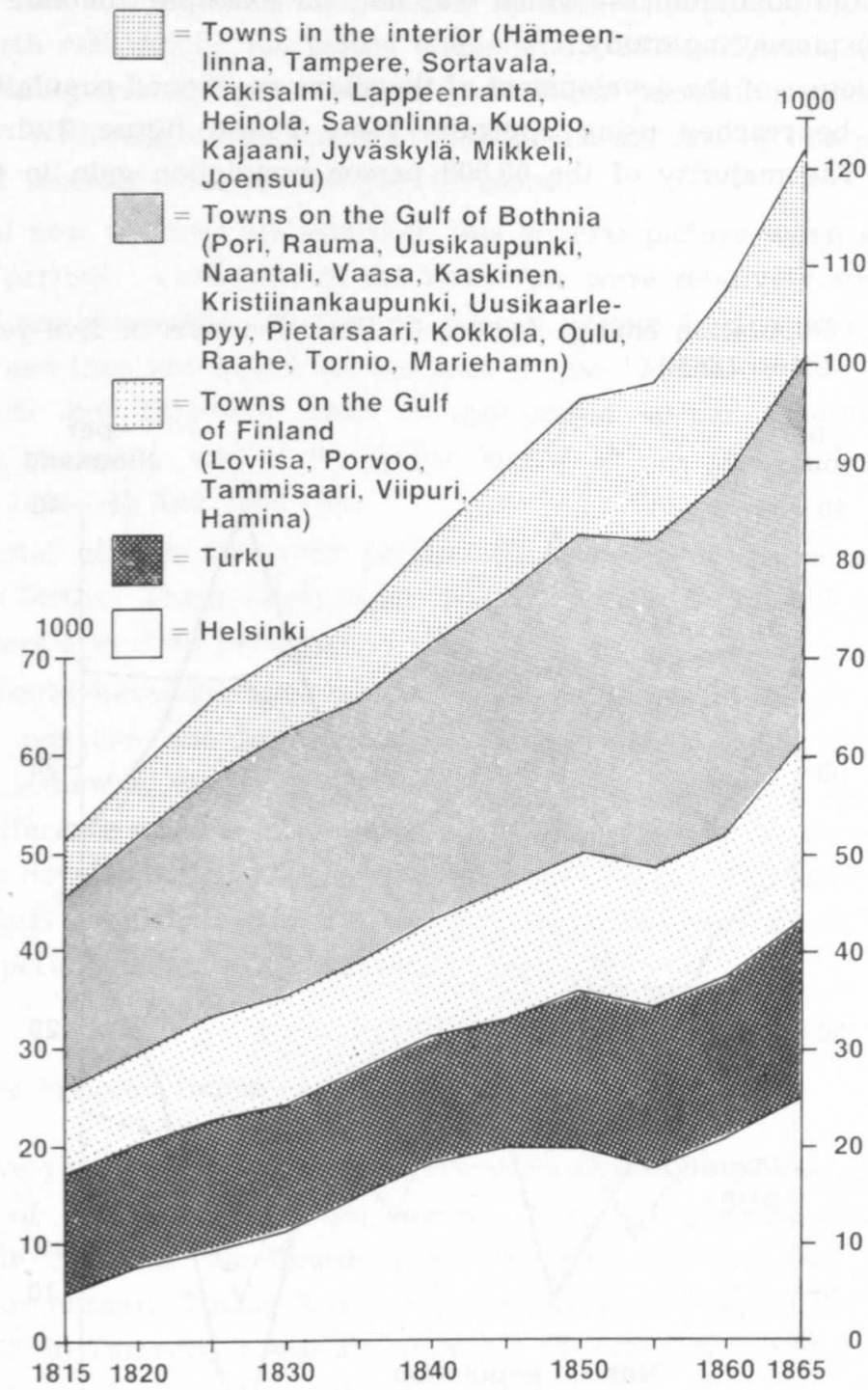

Much more problematic is the source situation concerning migration. No systematic information on persons migrating to and from towns is available before 1878. Thus for migration we will have to be satisfied with estimating only the migration difference, which is obtained by calculating the difference between the actual population gain and the natural gain/loss. This method is naturally imprecise, so that it can only be used to make a rough outline of the main directions of development. A closer inspection of annual variations, for 
example, is not possible, however. It also does not give information on the mobility of the population - which was not, for example, the case in Rosenberg's (1966) pioneering study.

A total picture of the development of the above mentioned population change factors can be reached using appendix table 2 and figure 2 drawn from this table. The majority of the 69,800 person population gain in the towns,

Figure 2. Population change factors in Finnish towns in five-year periods 1816-1865.

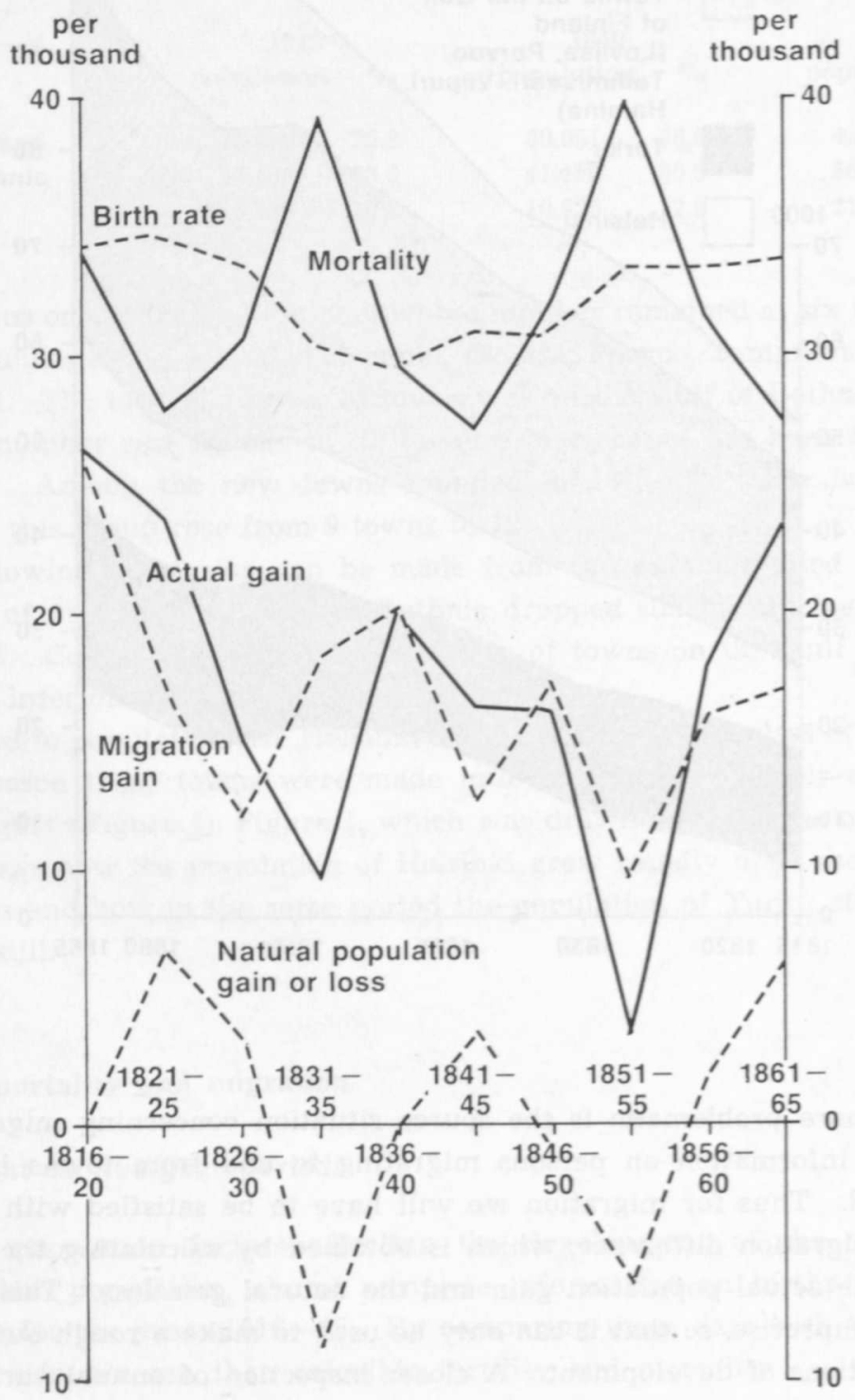


that is 67,000 inhabitants or about $96 \%$, was caused by migration gain, while only $4 \%$ (2,880 inhabitants) was caused by natural population increase. The annual birth rate during the period under study, 1816-65, was 32.4 per thousand, mortality was 31.7 per thousand and natural population gain was 0.7 per thousand. With migration gain at an average annual rate of 16.2 per thousand, the actual increase rose to 16.9 per thousand.

Several new features are added to this general picture when examined by five-year periods. Variations in the birth rate were relatively small, between 30 and 35 per thousand. On the other hand, strong fluctuations were felt in mortality and thus also in the natural gain or loss. Mortality was at its highest in $1831-35$ and $1851-55$, when it approached 40 per thousand. Correspondingly, mortality was at its lowest, below 30 per thousand, in 1821-25, $1836-40,1841-45$ and $1861-65$.

In a total of four five-year periods the number of deaths exceeded the number of births. The greatest losses were definitely in $1831-35$ and $1851-55$, at both times over 3,000 persons.

No definite developmental trend is thus apparent in the development of mortality, nor can one be seen for migration gain. Both were, however, relatively somewhat larger in 1816-40 than in the following 25-year period, but the difference was not large and in addition, examining by five-year periods makes the developmental trend zigzag back and forth. The same can also be said of actual population gain, for here the largest figures were in the first two five-year periods under study and also in $1861-65$.

\section{Differences between towns}

The five-year period fluctuations above were large, but the same can also be noted of differences between towns. Here the phenomenon is already apparent in the birth rate figures (Appendix table 3). While the birth rate in Loviisa, Tammisaari, Turku, Naantali and Kokkola was under 30 per thousand in 1816-65, in Tampere it was above 40 per thousand during the entire period under study, in Jyväskylä in 1841-65 and in Joensuu in 1851-65. Mortality fluctuated between 22 and 39 per thousand.

Natural population loss occurred in a total of ten towns - see figure 3 -, which when measured absolutely was greatest in Helsinki (2,715 persons), but when measured per thousand was greatest in Naantali (7.7 per thousand). Natural population gains were recorded in the other towns. Numerically it was highest in Tampere $(1,528)$, Kuopio $(1,412)$ and Oulu $(1,406)$. However, when measured per thousand Jyväskylä, Mikkeli and Joensuu grew more than these towns, but they were not included in the statistics until the end of the study period. 
All the towns experienced migration gain in 1816-65. Excluding Naantali, the migration gain was also sufficient to cover the natural population loss felt by the above-mentioned ten towns, so that actual population gain occurred. In dividing the towns into different groups according to the relative size of their migration gain, the following is arrived at:

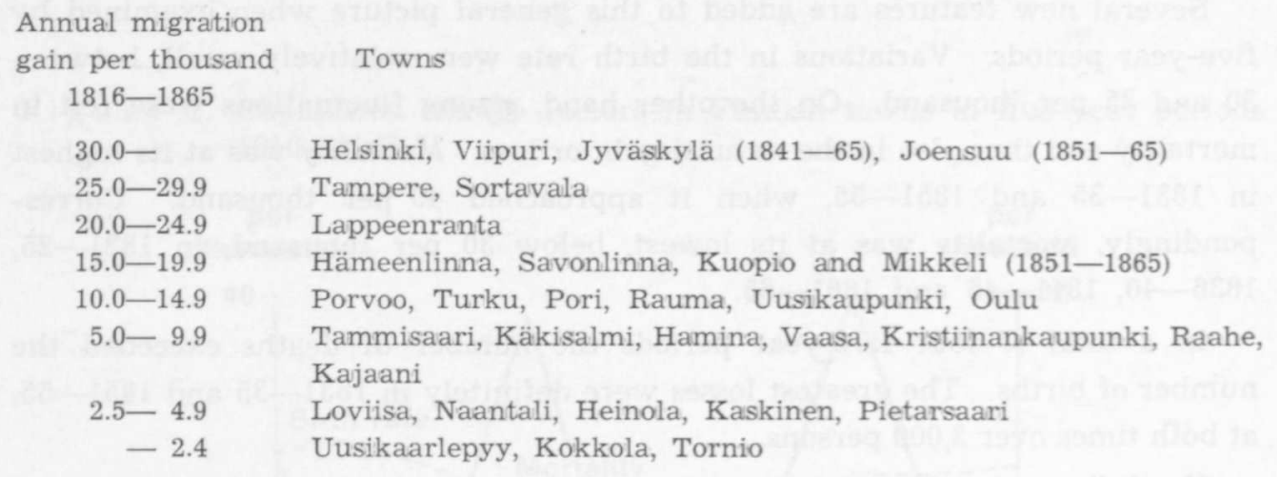

Figure 3. The absolute amount of natural population gain or loss in Finnish towns in 1816-1865.

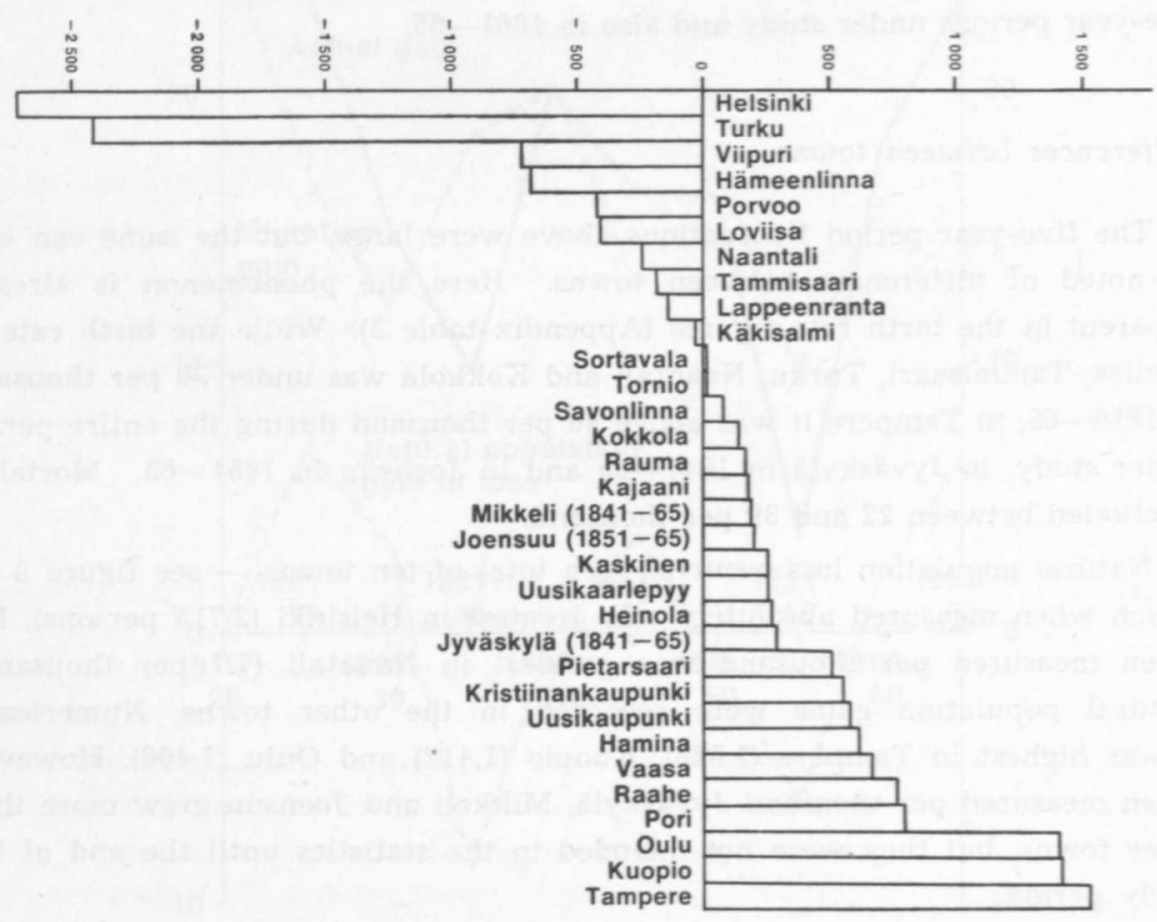


The largest annual migration gains were recorded in Helsinki, Viipuri, Jyväskylä and Joensuu. On the other hand, the migration gain of Uusikaarlepyy, Kokkola and Tornio was very slight.

Helsinki's proportion (23,074 persons) of the total absolute migration gain was truly great, for it formed about one-third $(34.5 \%)$. The following table shows that Turku and Viipuri were just as clearly in second and third place.

$\begin{array}{lclc}\text { Town } & \begin{array}{c}\text { Absolute } \\ \text { migration gain }\end{array} & \text { Town } & \begin{array}{c}\text { Absolute } \\ \text { migration gain }\end{array} \\ \begin{array}{l}\text { Helsinki } \\ \text { Turku }\end{array} & 23074 & \text { Porvoo } & 1605 \\ \text { Viipuri } & 8513 & \text { Uusikaupunki } & 1382 \\ \text { Pori } & 6255 & \text { Vaaisa } & 1209 \\ \text { Tampere } & 3704 & \text { Rauma } & 1130 \\ \text { Oulu } & 3222 & \text { Other towns } \\ \text { Kuopio } & 2694 & \text { (migration gain } \\ \text { Hämeenlinna } & 2446 & \text { in each under } & \\ & 2167 & \begin{array}{l}\text { 1 000 persons) } \\ \text { Total migra- }\end{array} & 9570 \\ & & \text { tion gain } & 66971\end{array}$

A migration gain of over 3,000 persons was also recorded in Pori and in Tampere, while Oulu, Kuopio and Hämeenlinna exceeded 2,000. A quite large migration gain was also found in Porvoo, Uusikaupunki, Vaasa and Rauma. In the other towns - a total of 20 - the migration gain totaled 9,570 persons or only $14.3 \%$ of the entire migration gain $(66,971$ persons).

The migration gain in the towns also, of course, affected the age structure. This is demonstrated in figure 4, which describes the situation in 1845. Compared to the rural areas, the urban age structure differed in many respects. There were relatively less young, under 15-year-olds in the towns than in the rural areas. On the other hand, the situation among the 15-50-year-olds was the opposite; the difference was especially great in the 20 - 34-year-old group.

\section{General background factors}

What were the basic reasons causing the population in the towns of Finland to more than double in $1815-65$ ? And why was the population growth in the various towns so very different? Before we attempt to answer these questions, we should first compare the growth of the urban population with the development of the entire population of Finland. From the figures shown here we 
Figure 4. The age structure of the urban and rural population in Finland in 1845 .
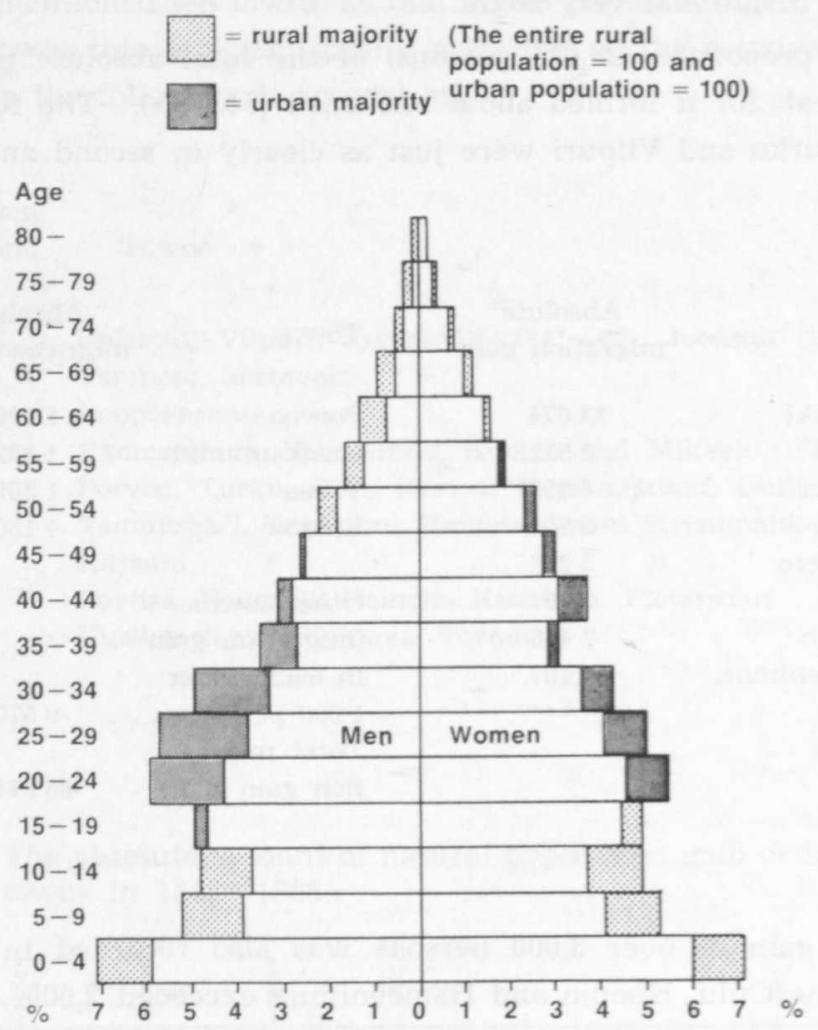

can see that in 1815 the proportion of the population living in towns was 4.7 and in 1865 it was 6.7. By 1840, the percentage had risen by 1.1 percentage points. Then the figure remained stationary for quite a long time, at slightly under six percent. Not until the end of the 1850 s did the percentage begin to climb quite rapidly.

$\begin{array}{cccc}\begin{array}{c}\text { Year } \\ \begin{array}{c}\text { December } \\ 31 \text { st }\end{array}\end{array} & \begin{array}{c}\text { Urban population } \\ \text { as } \% \text { of Finnish } \\ \text { population }\end{array} & \begin{array}{c}\text { Year } \\ \text { December } \\ 31 \text { st }\end{array} & \begin{array}{c}\text { Urban population } \\ \text { as \% of Finnish } \\ \text { population }\end{array} \\ 1815 & 4.7 & 1845 & 5.8 \\ 1820 & 5.0 & 1850 & 5.9 \\ 1825 & 5.2 & 1855 & 5.8 \\ 1830 & 5.2 & 1860 & 6.2 \\ 1835 & 5.3 & 1865 & 6.7 \\ 1840 & 5.8 & & \end{array}$


This examination should also include a mention of development in the $1700 \mathrm{~s}$, even though Finland at that time was geographically different. Namely, in 1727 the population of the towns formed $4.5 \%$ of the entire population, but the proportion rose by 1785 to $5.3 \%$, but dropped again to $4.5 \%$ by 1810 (Turpeinen 1977 , p. 116). Thus over a longer span of time the percentage had not been constantly on the rise. In fact, a small decline is apparent also between 1850 and 1855 , when the percentage dropped slightly.

In discussing the background factors affecting the development of the population in the towns we can begin with Finland's altered political situation. How did the annexation of Finland to Russia as an autonomous region in 1809 and the designation of Helsinki as the capital of the Grand Duchy in 1812 affect the development of the urban population? If we examine the proportions of Turku and Helsinki in the entire urban population of Finland in 1749-1865, we arrive at the following:

1749

Helsinki

Turku
Percentage of the Finnish urban population $\begin{array}{llll}1805 & 1810 & 1815 & 1840\end{array}$

7.7

25.9
9.0

25.8
9.4

26.2
22.0

16.0
1865

20.8

15.0

The change in government was not apparent immediately in the percentages of Turku and Helsinki, which is quite understandable, because even many of the central organs of the state were located in Turku for many years at the beginning of the autonomous period. The actual profound change was not felt until 1815-40, when Helsinki's percentage rose from 9.4 to 22 and correspondingly Turku's dropped from 26.2 to 16 percent. Then the situation stabilized and the percentage figures remained almost unchanged; there was even a very slight decline, about one percent, apparent in 1865 in both towns.

This change in the proportions of Helsinki and Turku also had a decisive effect on the percentages of the towns on the Gulf of Bothnia and the Gulf of Finland. Without Turku and Helsinki the development of these two groups would namely have been the following.

Percentage of the Finnish urban population $1815 \quad 1840 \quad 1865$

Towns on the Gulf of Finlend (excluding Helsinki)

14.6

14.9

Towns on the Gulf of Bothnia (excluding Turku)

38.4

34.5

31.5

As can be seen, the proportion of the towns on the Gulf of Bothnia shrank somewhat even without Turku, but not very sharply. On the other hand, the towns on the Gulf of Finland, excluding Helsinki, did not increase their share, 
instead they lost two percent in 1815-65. Thus when the towns of Finland turned their "faces» from Stockholm to St. Petersburg, this was mainly caused by the rise of Helsinki and the relative decline of Turku. Also the fact that the urban population's percentage of the entire country's population rose in $1815-40$ by about one percentage point is largely due to Helsinki's position and to the autonomous position of the country in general. Namely, when Finland became an autonomous region the size of the administration increased somewhat, which also had indirect effects: the administration and government officials needed servants, which together caused demand on the areas of commerce and handcrafts.

And how can the rise of the proportion of the urban population in relation to the entire population at the end of the period under study be explained? Quite obviously, it was connected mainly with the beginning of industrialization, which included the growth of lumbering. This is shown by the fact that, in addition to Helsinki, Turku, Viipuri and Kuopio, the populations of Oulu and Pori, among others, also grew rapidly in 1855-65. These last two towns were situated notably on two important river waterways - and thus also at the mouths of rivers on which logs were floated.

The factors mentioned above can be used to understand the changes which took place in the percentages of the towns. On the other hand, the growth of the urban population cannot be separated from the general growth of the population. Thus the question of why Finnish towns grew in the preindustrial era - this had continued at least from the $1720 \mathrm{~s}$ - is connected to a broader question: why did Europe's rapid population growth begin in the $1700 \mathrm{~s}$. We will not go into this broader question here, however. 


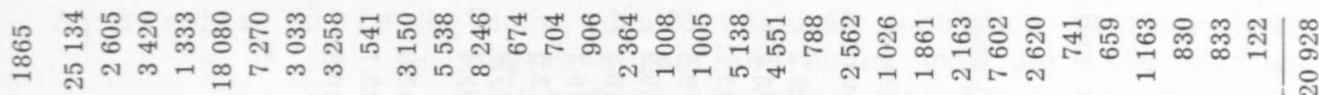

ஜ

lర

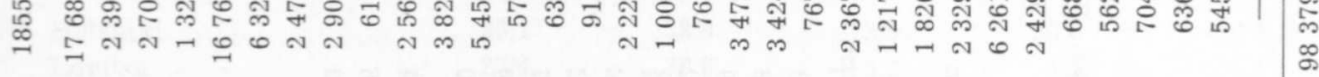

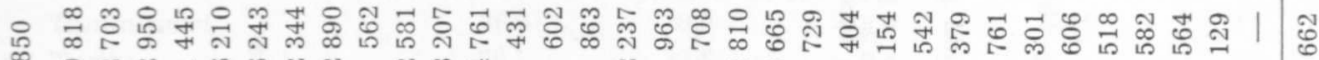

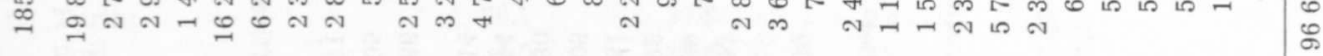

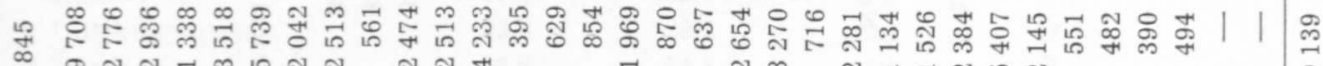

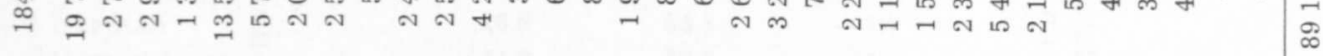

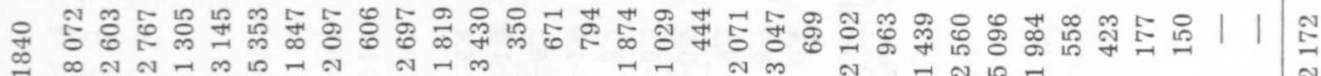

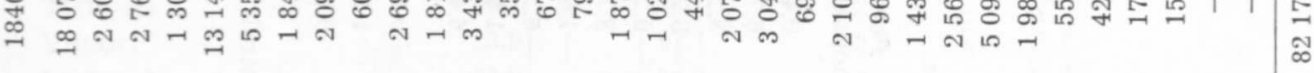

以

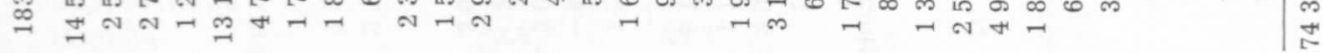

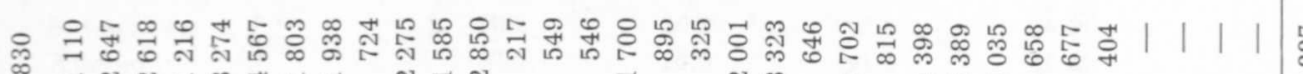

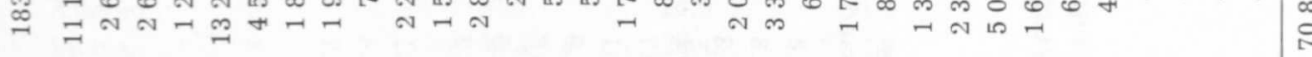

เ

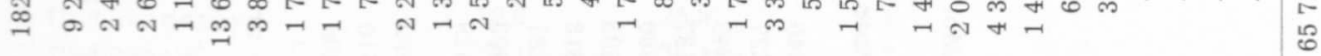

골 :

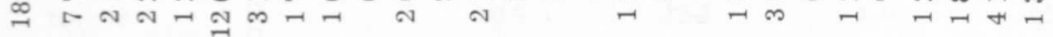

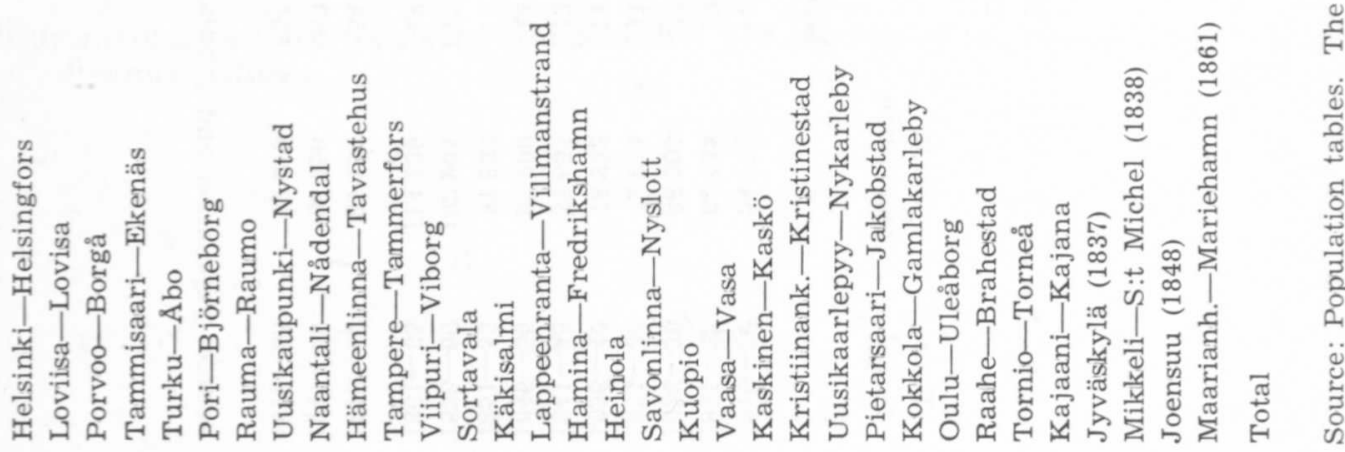




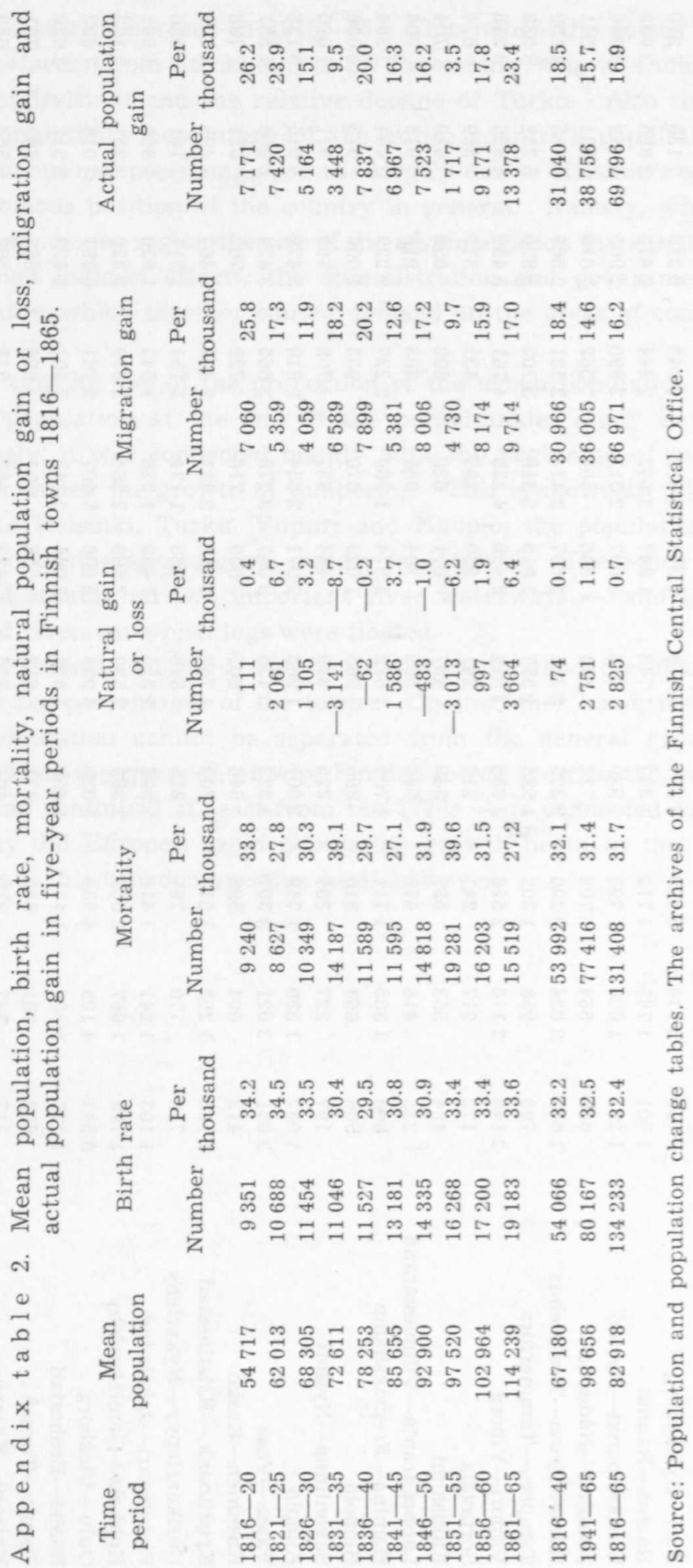


Appendix table 3. Births, deaths, natural population gain or loss, migration gain and actual gain per 1000 persons of the mean population annually in Finnish towns in 1816-1865.

$\begin{array}{lcccrr}\text { Town } & \text { Births } & \text { Deaths } & \begin{array}{c}\text { Natural } \\ \text { population } \\ \text { gain or loss }\end{array} & \begin{array}{r}\text { Migration } \\ \text { gain }\end{array} & \begin{array}{r}\text { Actual } \\ \text { gain }\end{array} \\ \text { Helsinki } & & & & \\ \text { Loviisa } & 35.1 & 38.6 & -3.5 & 30.0 & 26.5 \\ \text { Porvoo } & 27.4 & 30.6 & -3.2 & 4.6 & 1.4 \\ \text { Tammisaari } & 30.3 & 33.3 & -3.0 & 11.7 & 8.7 \\ \text { Turku } & 26.0 & 28.9 & -2.9 & 9.6 & 6.7 \\ \text { Pori } & 29.1 & 32.5 & -3.4 & 11.9 & 8.5 \\ \text { Rauma } & 34.0 & 30.9 & 3.1 & 14.2 & 17.3 \\ \text { Uusikaupunki } & 33.8 & 32.2 & 1.6 & 10.8 & 12.4 \\ \text { Naantali } & 33.3 & 28.2 & 5.1 & 12.1 & 17.2 \\ \text { Hämeenlinna } & 26.6 & 34.3 & -7.7 & 3.6 & -4.1 \\ \text { Tampere } & 31.8 & 37.2 & -5.4 & 17.3 & 11.7 \\ \text { Viipuri } & 40.2 & 28.1 & 12.1 & 25.6 & 37.7 \\ \text { Sortavala } & 33.9 & 37.7 & -3.8 & 32.8 & 29.0 \\ \text { Käkisalmi } & 32.9 & 32.0 & 0.9 & 28.7 & 29.6 \\ \text { Lappeenranta } & 30.3 & 31.5 & -1.2 & 7.3 & 6.1 \\ \text { Hamina } & 31.6 & 36.1 & -4.5 & 20.9 & 16.4 \\ \text { Heinola } & 33.8 & 27.3 & 6.5 & 9.2 & 15.7 \\ \text { Savonlinna } & 31.3 & 25.2 & 6.1 & 3.3 & 9.4 \\ \text { Kuopio } & 30.2 & 26.9 & 3.3 & 19.3 & 22.6 \\ \text { Vaasa } & 37.2 & 26.0 & 11.2 & 19.3 & 30.5 \\ \text { Kaskinen } & 32.3 & 28.4 & 3.9 & 7.2 & 11.1 \\ \text { Kristiinankaupunki } & 34.8 & 27.5 & 7.3 & 3.2 & 10.5 \\ \text { Uusikaarlepyy } & 32.9 & 27.3 & 5.6 & 8.6 & 14.2 \\ \text { Pietarsaari } & 30.6 & 25.5 & 5.1 & 1.3 & 6.4 \\ \text { Kokkola } & 32.1 & 25.4 & 6.7 & 3.3 & 10.0 \\ \text { Oulu } & 28.8 & 27.5 & 1.3 & 1.8 & 3.1 \\ \text { Raahe } & 30.5 & 25.3 & 5.2 & 10.1 & 15.3 \\ \text { Tornio } & 30.9 & 22.9 & 8.0 & 7.3 & 15.3 \\ \text { Kajaani } & 31.5 & 31.0 & 0.5 & 1.3 & 1.8 \\ \text { Jyväskylä (1841-65) } & 39.5 & 31.6 & 7.9 & 7.2 & 15.1 \\ \text { Mikkeli (1841-65) } & 41.4 & 23.5 & 17.9 & 41.3 & 59.2 \\ \text { Joensuu (1851-65) } & 36.5 & 24.2 & 12.3 & 15.5 & 27.8 \\ & 46.8 & 22.0 & 24.8 & 66.3 & 91.1\end{array}$

Source: Population and population change tables. The archives of the Finnish Central Statistical Office. 


\section{Bibliography}

Ahonen, Felix: Kajaanin kaupungin historia III. Kajaani 1961.

Aspelin, H.Em.: Wasa stads historia. Nikolaistad 1892.

Castrén, Liisa: Lappeenrannan kaupungin historia 1812-1918. Lappeenranta 1957.

Cederberg, A. R.: Heinola maaherran residenssinä (Heinolan kaupungin historia). Tampere 1948.

Cederlöf, Johannes: Ekenäs stads historia III. Ekenäs 1964.

Granit, (G:T) B.: Muistelmia Kuopion kaupungin satavuotisen olemassa-olon ajalta. Kuopio 1882.

Halila, Aimo: Ks. Nordenstreng.

Hartman, Torsten: Borgå stads historia III. Borgå 1908.

Hautala, Kustaa: Oulun kaupungin historia III. Oulu 1975.

Innamaa, Kerttu: Naantalin historia III. Turku 1965.

Joensuun kaupunki 1848-1948. Helsinki 1949.

Jutikkala, Eino: Städernas tillväxt och näringsstruktur (Urbaniseringsprosessen i

Norden, del 3, red. G. A. Blom). Oslo-Bergen-Tromsø 1977.

Jutikkala, Eino: Turun kaupungin historia 1856-1917 I. Turku 1957.

Kristinestads historia. Kristinestad 1915.

Kaukovalta, Kyösti: Uudenkaupungin historia III. Uusikaupunki 1930.

Kuujo, Erkki: Entisajan Mikkeli. Mikkeli 1971.

Lindeqvist, K. O.: Hämeenlinnan kaupungin historia III. Hämeenlinna 1930.

Lähteenoja, Aina: Rauman kaupungin historia IV. Rauma 1939.

Möller, Sylvi: Gamlakarleby stads historia III. Borgå 1973.

Nikander, Gabriel: Lovisa stads historia II. Lovisa 1932.

Nikula, Oscar: Kaupunkilaitos 1721-1875 (Suomen kaupunkilaitoksen historia I). Vantaa 1981.

Nikula, Oscar: Turun kaupungin historia 1809-1856. Turku 1972.

Nordenstreng, Sigurd - Halila, Aimo: Haminan historia II. Mikkeli 1975.

Ojala, Veikko: Heinolan kaupunki 1839-1917 (Heinolan kaupungin historia). Tampere 1948.

Puramo, Eino: Käkisalmen kaupungin ja maalaiskunnan historia II (Käkisalmen historia). Lahti 1958.

Pääpiirteet Suomen väestötilastosta vuosina 1750 -1890 I. Väestön tila (Suomenmaan virallinen tilasto VI, Väkiluvun tilastoa 29). Helsinki 1899.

Rosenberg, Antti: Muuttoliike Uudenmaan läänissä esi-industrialistisen kauden lopulla (1821-1880). Historiallisia tutkimuksia LXX. Helsinki 1966.

Rosenberg, Antti: Väestöolot 1721-1870 (Hämeen historia III: 2). Hämeenlinna 1976.

Ruuth, J. W.: Björneborgs stads historia. Helsingfors 1897.

Ruuth, J. W.: Viborgs stads historia. Helsingfors 1906.

Saarenheimo, Mikko: Savonlinnan kaupungin historia II. Kuopio 1963.

Saarinen, J.: Porin kaupungin historia III. Kokemäki 1972.

Sjöblom, Walter: Mariehamns stads historia 1861-1911. Mariehamn 1911.

Söderhjelm, Alma: Brahestad 1649-1899. Helsingfors 1911.

Söderhjelm, Alma: Jakobstads historia III. Helsingfors 1914.

Tiainen, Jorma: Hitaan kehityksen kausi 1812-n. 1880 (Sortavalan kaupungin historia). Jyväskylä 1970 .

Tommila, Päiviö: Jyväskylän kaupungin historia 1837-1965 I-II. Jyväskylä 1972.

Tornio 1621-1921. Oulu 1921.

Turpeinen, Oiva: De finländska städernas folkmängd 1727-1810 (Historisk Tidskrift för Finland 1977:2).

Vaarama, Edv.: Kuopion kaupungin historia II. Kuopio 1932. 
Waris, Heikki: Helsinkiläisyhteiskunta (Helsingin kaupungin historia III: 2). Helsinki 1950.

Wichmann, V. K. E.: Nykarleby stad. Helsingfors 1920.

Wirilander, Kaarlo: Savon historia III. Kuopio 1960.

Voionmaa, Väinö: Tampereen kaupungin historia II, Tampere 1929 ja III, Tampere 1932.

Väkiluku- ja väestönmuutostaulut 1815-1865 (Suomen tilastokeskuksen arkisto). 